\title{
Assessment and rehabilitation of a deteriorated heat pipeline overpass
}

\author{
Marta Lutomirska $^{1 *}$, Tomasz Lutomirski ${ }^{2}$ \\ ${ }^{1}$ Warsaw University of Technology, 00-661Warsaw, Poland \\ ${ }^{2}$ Gaz-System S.A., 02-337 Warsaw, Poland
}

\begin{abstract}
A deteriorated heat pipeline overpass was subjected to assessment and rehabilitation. Lack of technical documentation, increased loading, and changing design codes had to be taken into consideration. The numerous damages and their origin were identified. Special attention was paid to corrosion at the connection zones, being the result of inadequate paint coating, aggressive environment, and leakages for technological installations. The structure was originally designed according to the design code PN-62/B-03200 from the 1960's using the permissible stress method. After rehabilitation it was supposed to fulfil current requirements of Eurocodes. Static strength analyses were performed for both codes and the differences between them were noted. The methods for rehabilitation were limited by the requirement of limited intervention and maintaining the structure under service. The applied solution for the strengthening in form of the steel profiles welded to the existing structure is described.
\end{abstract}

\section{Introduction}

Assessment and rehabilitation of existing structures are very often more challenging than constructing a new structure. They tend to provoke problems of complex origins. Access to complete technical documentation is highly valued and not always possible [1]. As-built documentation may not be reliable and it should be compared with the existing structure, taking into consideration materials used, quality of workmanship, and manner of exploitation. Then the localization, type, magnitude and origin of damages must be identified to provide the optimal solution for rehabilitation. The control calculations should be performed accounting for incompatibility of the design codes, which were changing within years of exploitation.

Pipeline overpasses are special industrial structures, usually extended for many kilometres above terrain, which makes them sensitive to corrosion $[2,3]$. The heat pipeline overpass described in this paper was supposed to undergo rehabilitation, which means restoring it to service level. It was required to keep the structure under service and to limit the intervention in the existing structure. In the present paper, the assessment of the

\footnotetext{
* Corresponding author: m.lutomirska@il.pw.edu.pl
} 
deteriorated heat pipeline overpass, the results of static strength analysis according to old and current design codes, and methods undertaken for the rehabilitation are presented.

\section{Description of the assessed pipeline overpass}

The assessed heat pipeline overpass (figure 1) is located in a chemical plant. It was constructed in the 1960's to supply the plant and the city [4]. Its total length is about $265 \mathrm{~m}$. The steel space trusses forming the structure of the overpass are collocated on the supports, with a slope of $3 \%$. The supports are pinned and fixed, and they reach about $7 \mathrm{~m}$ above the terrain level. The fixed supports, applied at the ends of every second segment approximately, are space truss columns of rolled steel profiles. The rest of the supports are pinned. They are two-dimensional reinforced concrete frames with two girders. The overpass consists of the space trusses spanning 18.0,21.0, and $24.0 \mathrm{~m}$ and $6.0 \mathrm{~m}$ long connectors. They consist of two parallel two-dimensional trusses spaced $2930 \mathrm{~mm}$, which is a fixed external distance between the profiles. The trusses are joined with X-shape bracings at the top and at the bottom (see figure 2). The verticals and diagonals divide the top and bottom chords of the truss into variable sections between $4210 \mathrm{~mm}$ and $2280 \mathrm{~mm}$. For the top and bottom chords different double $C$ shape profiles are used: 240, 220, 200, 180 and $160 \mathrm{~mm}$, spaced every $160 \mathrm{~mm}$. This results in variable distance between longitudinal axes of the profiles from 2690 to $2750 \mathrm{~mm}$. The change of the distances between axes occurs even twice within one segment of the structure. Collocation of the verticals and diagonals in between webs of $\mathrm{C}$ shaped profiles allowed for decreasing the gusset plates sizes, or even their elimination in case of connections between the chords and verticals. For the verticals, double angle profiles $\llcorner 60 \times 40 \times 6$ and $\llcorner 75 \times 50 \times 8$ were applied. For the diagonals the following profiles were used: double $C$ shapes $160 \mathrm{~mm}$ and angle profiles $2\llcorner 120 \times 80 \times 10,2\llcorner 100 \times 75 \times 8$, and $2\llcorner 75 \times 50 \times 8$. The ends of the top and the bottom chords of the truss are supported on $7.50 \mathrm{~m}$ long transverse girders, which consist of $180 \mathrm{~mm}$ double C-shape profiles. The transverse girders support also the platform grates and balustrades. The number of pipelines carried by the overpasses is usually 16 . However, the maximum number of pipelines is 23 . In figure 3 , an example of the cross-section with 18 pipelines is shown. The pipelines at the top are destinated for transfer of water steam, while those at the bottom carry water. A thermal insulation of mineral wool is applied, $100 \mathrm{~mm}$ for pipelines of diameter $500 \mathrm{~mm}$ and more, and 60 to $80 \mathrm{~mm}$ for the pipelines of lower diameter.

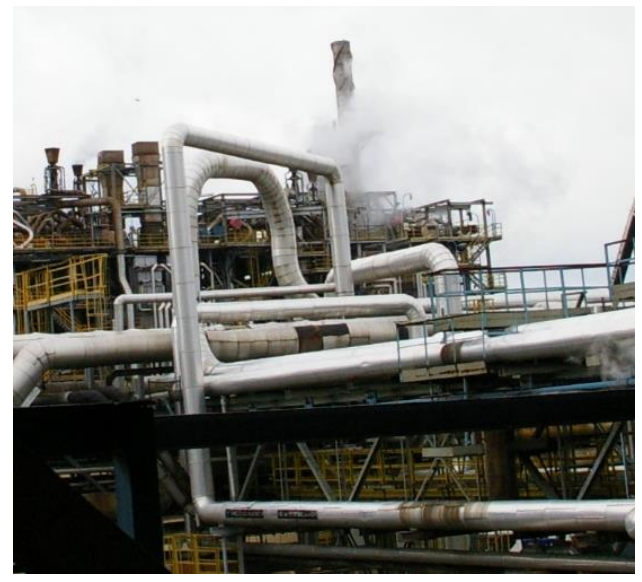

Fig. 1. General view of the pipeline overpass. 
a)

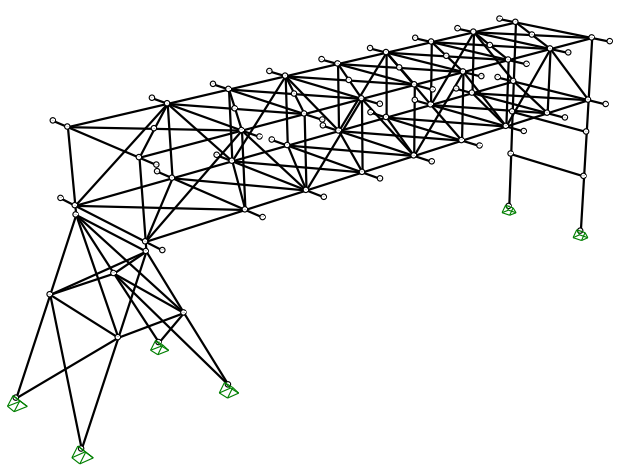

b)

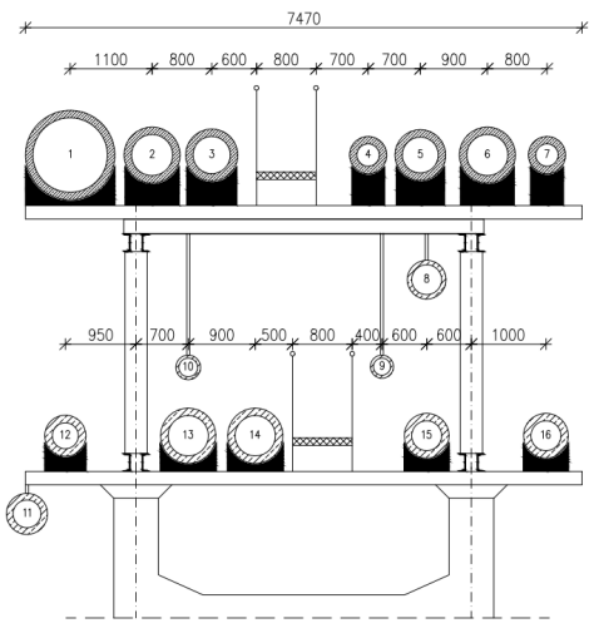

Fig. 2. The space truss structure of the overpass: a) 3D model b) cross section.

\section{Assessment of damages to the structure}

A site inspection was carried out from the terrain and platform levels in order to assess the magnitude of damage to the structure of the overpass. It was observed that during many years of exploitation, additional pipelines have been added increasing loading to the structure. The deformation of the verticals and bracings (figure 3a) were consequences of assembly of new members and inadequate strengthening. At the bottom parts of the overpass, especially at the nodes, very advanced corrosion was visible (figure $3 \mathrm{~b}$ ). In the majority, it was a type of surface corrosion. In some places, pitting corrosion was also observed. The corrosion was a result of inadequate protection in an aggressive environment. Due to localization on the premises of a chemical plant, the overpass structure made of carbon steel required frequent renovation of the paint coating [5]. Particularly sensitive to corrosion were the closed zones in the connections of the truss members, which do not allow for fast drainage of rainwater. Additional factors accelerating the corrosion process were leakages from the technological installations, and excessive displacements on the supports being the result of improperly designed compensation of the pipelines.

Irregular and porous surface of reinforced concrete frames were found unprotected against the influence of the aggressive environment. It was deteriorated due to cyclic environmental actions like: water saturation and drying, freezing, and thawing. Penetration of water and air through cracks and micro cracks in concrete led to corrosion of steel reinforcement. The results of volume changes of the corroded steel reinforcement were splitting, spalling of concrete, and local losses of concrete cover (see figures $4 \mathrm{a}, 4 \mathrm{~b}$ ). The depth of the carbonization evaluated based on the phenolphthalein method was up to $4 \mathrm{~cm}$. The measured thickness of the concrete cover was very variable from 10 to $35 \mathrm{~mm}$. The concrete class evaluated based on sclerometric method was between C16/20 and C20/25. 
a)

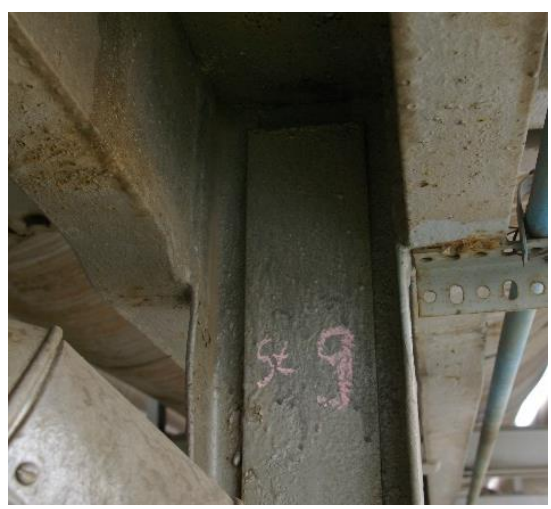

b)

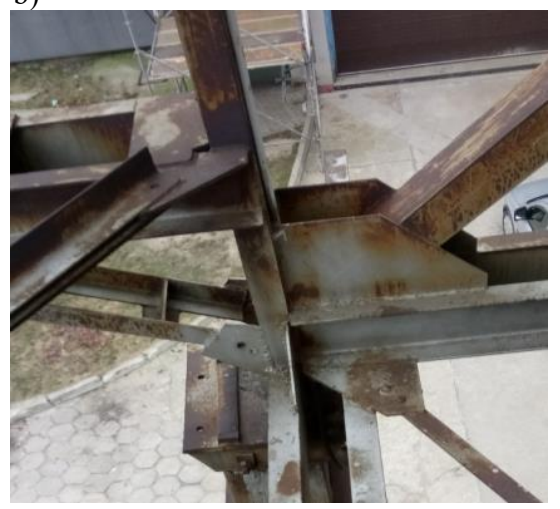

Fig. 3. Damages to the steel structure of the overpass: a) deformation of a vertical b) corrosion at the truss node.

a)

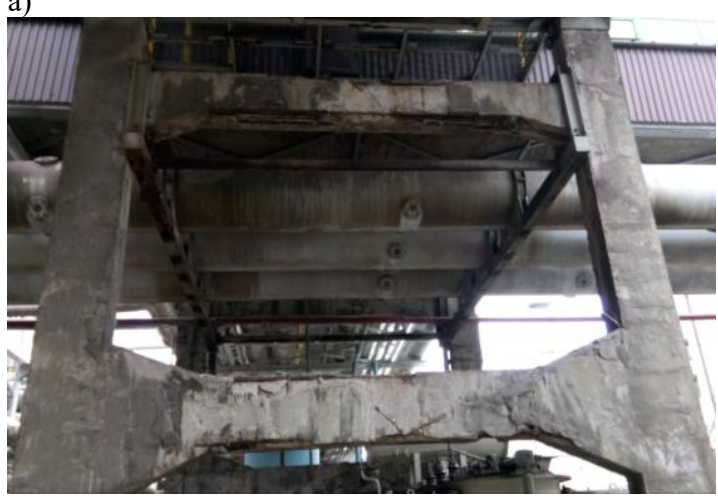

b)

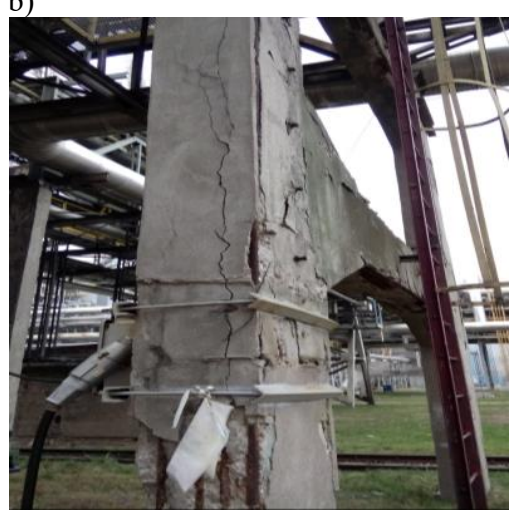

Fig. 4. Damages to the concrete frame: a) girders b) column.

\section{Static strength analysis and strengthening of the overpass}

\subsection{Introduction}

For the analysed structure, only scant documentation was available. No archival static strength calculations were preserved. Exact data for the introduced changes to the structure, additional pipelines and single strengthening members, are also unknown. Incompatibility of the old design codes used at the times of construction [6] of the overpass and the actual Eurocodes [7, 8, 9] arise concern about assessment of safety of the structure. There are significant differences in the approach to calculate the load bearing capacity of the structural elements, checks of the ultimate and serviceability limit states. Another issue are the effects of actions, which in the Eurocodes are much higher than in the PN-B design codes. The change in climatic loads results, inter alia, from assumed return period, which is 50 -year in the Eurocodes and 5-year in the PN-B. Therefore, the performed static strength calculations consider the existing structure, without previous strengthening, and are carried out using old as well as current design codes [10]. In the analyses, the internal forces in the truss members were derived using computer methods. The calculations presented below concern one selected part of the structure. 


\subsection{Evaluation of the load bearing capacity for the overpass before strengthening according to PN-62/B-03200 and EN 1993-1-1:2005}

It is highly probable, that at the times of the designing of the structure, the internal forces in the truss members were derived for a plane model Cremona diagram, assuming hinges at all connections of the bars. The results from these kinds of analysis insignificantly vary comparing to the more realistic model assuming continuous chords, up to $3 \%$ for the truss diagonals and up to $1 \%$ for the truss verticals. Buckling lengths of truss members $1_{w}$, except support zone, were assumed as:

- $\quad$ in the plane of the truss - equal to 0.8 of the theoretical bar length 1 ,

- $\quad$ in the plane perpendicular - equal to the theoretical bar length 1 .

The capacity utilization rate according to PN-62/B-03200 was calculated using the formula:

$$
U_{P N-62}=\frac{N_{\max }}{\beta \cdot A \cdot k_{I}}
$$

where: $N_{\max }$ is the highest axial force in the compressed bar, $\beta$ is a buckling coefficient for steel corresponding to the calculated slenderness, $\mathrm{A}$ is area of the cross section, $k_{I}$ is a permissible compressive stress in steel.

Value of coefficient $\beta$ depends on slenderness $\lambda$ and steel class and can be found in the table in PN-62/B-03200. Compound bars of constant cross sections were calculated for buckling in the plane perpendicular to axis y-y (crossing the profiles) and for buckling in the plane perpendicular to axis $\mathrm{z}-\mathrm{z}$ (not crossing the profiles).

$$
\lambda_{y}=\frac{l_{w}}{i_{y}},
$$

For the bars with battens the slenderness $\lambda_{z}^{\prime}$ is calculated as:

$$
\lambda_{z}^{\prime}=\lambda_{z} \sqrt{1+\left(\frac{\lambda_{1}}{\lambda_{z}}\right)^{2}}
$$

where: $\lambda_{y}$ is slenderness of bar about axis $y-y, \lambda_{z}$ is slenderness of bar about axis $z-z, \lambda_{1}$ is slenderness of free part of chord $\lambda_{1}=\frac{l_{1}}{i_{1}}, l_{1}$ is axial distance between battens, $i_{1}$ is the smallest radius of gyration of the single profile cross section.

The capacity utilization ratio was calculated according to EN 1993-1-1:2005 and Kozłowski [11]. For in-plane buckling the following formula was used:

$$
U_{E N 3_{y-y}}=\frac{N_{c h, E d}}{\frac{\chi y^{\cdot} N_{b, c h, R k}}{\gamma_{M 1}}}
$$

where $N_{c h, E d}$ is design value of compression force in a member, $\chi_{y}$ is reduction factor for the relevant buckling mode, $N_{c h, E k}$ is the characteristic buckling resistance of a single compression member, $\gamma_{M 1}$ is partial safety factor for resistance of member to buckling

The capacity utilization ratio for out-of-plane buckling was calculated using the formula:

$$
U_{E N 3_{z-z}}=\frac{N_{c h, E d}}{\frac{\chi_{z 1} N_{c h, R k}}{\gamma_{M 1}}}+k_{z z} \frac{M_{c h, Z 1, E d}}{\frac{M_{c h, z 1, R k}}{\gamma_{M 1}}}
$$

where $N_{c h, E d}$ is design value of compression force in a member, $\chi_{z 1}$ is reduction factor for the relevant buckling mode, $N_{c h, R k}$ is the characteristic buckling resistance for a single compression member, $\gamma_{M 1}$ is partial safety factor for resistance of member to buckling, $k_{z z}$ is interaction coefficient, $M_{c h, z 1, E d}$ is design value of moment in a member, $M_{c h, z 1, R k}$ is the characteristic buckling resistance moment. 
The results were obtained for two cases of loading. In the first case, real loading with the pipelines filled with water or steam was considered. In the second case, an asymmetric loading being an effect of all pipelines filled with water was studied. The results were presented in table 1 . It can be noticed that the capacity utilization ratio is quite varied and for some members of the truss is not adequate.

Table 1. Capacity utilization ratio for truss members before strengthening, $y-y$

\begin{tabular}{|c|c|c|c|c|}
\hline Bar & Cross-section & PN-62/B-03200 & \multicolumn{2}{|c|}{ PN-EN 1993-1-1 } \\
\hline & & steam and water & water and steam & water \\
\hline 17 & $2 \mathrm{~L} 60 \times 40 \times 6$ & 0.29 & 0.39 & 0.71 \\
\hline 18 & 2L75x50x8 & 0.55 & 0.65 & 0.93 \\
\hline 19 & 2L60x40x6 & 0.27 & 0.37 & 0.68 \\
\hline 21 & $2 \mathrm{~L} 120 \times 80 \times 10$ & 0.71 & 0.74 & 1.05 \\
\hline 22 & 2L120x80x10 & 1.25 & 1.01 & 1.44 \\
\hline
\end{tabular}

Table 2. Capacity utilization ratio for truss members before strengthening, $\mathrm{z}-\mathrm{z}$

\begin{tabular}{|c|c|c|c|c|}
\hline Bar & Cross-section & PN-62/B-03200 & \multicolumn{2}{|c|}{ PN-EN 1993-1-1 } \\
\hline & & steam and water & water and steam & water \\
\hline 17 & 2L60x40x6 & 0.20 & 0.15 & 0.29 \\
\hline 18 & $2 \mathrm{~L} 75 \times 50 \times 8$ & 0.32 & 0.27 & 0.39 \\
\hline 19 & 2L60x40x6 & 0.19 & 0.15 & 0.27 \\
\hline 21 & 2L120x80x10 & 0.53 & 0.51 & 0.75 \\
\hline 22 & 2L120x80x10 & 0.69 & 0.61 & 0.92 \\
\hline
\end{tabular}

\subsection{Strengthening of the overpass structure}

The strengthening of the overpass was expected to be carried out under working conditions. Even partial closure was not permitted. There were no simple methods to unload the structure for the time of rehabilitation. Different solutions for strengthening were considered. Finally, the adopted solution included the addition of steel profiles to the utmost critical truss members. The new profiles were welded to the existing ones, assuring that the axes in the plane of the truss are not changed [12]. For the strengthening steel S235 was used, so the yield strength of the steel is the same as in the existing structure (steel St3S). An exemplary strengthening was shown in figure 5 and 6.

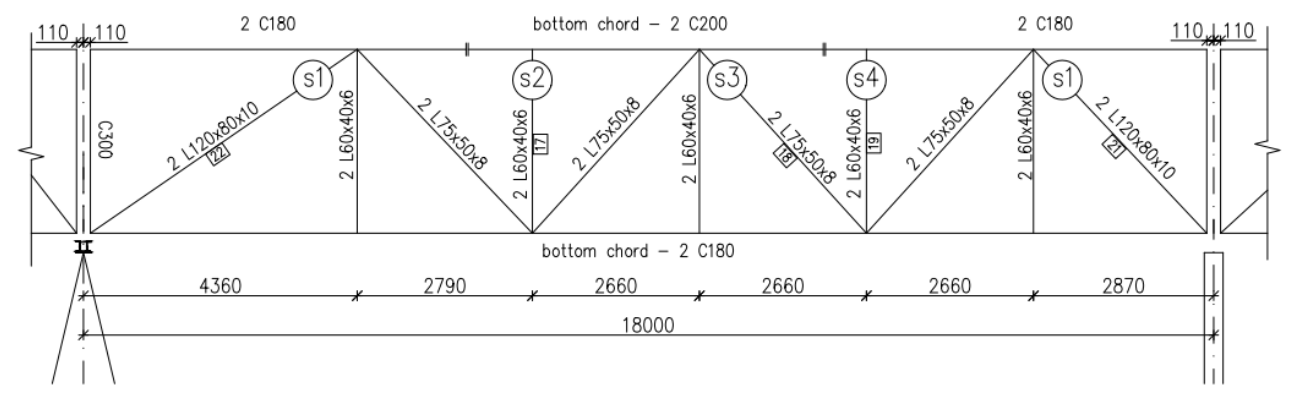

Fig. 5. Localization of the strengthened members in the truss. 

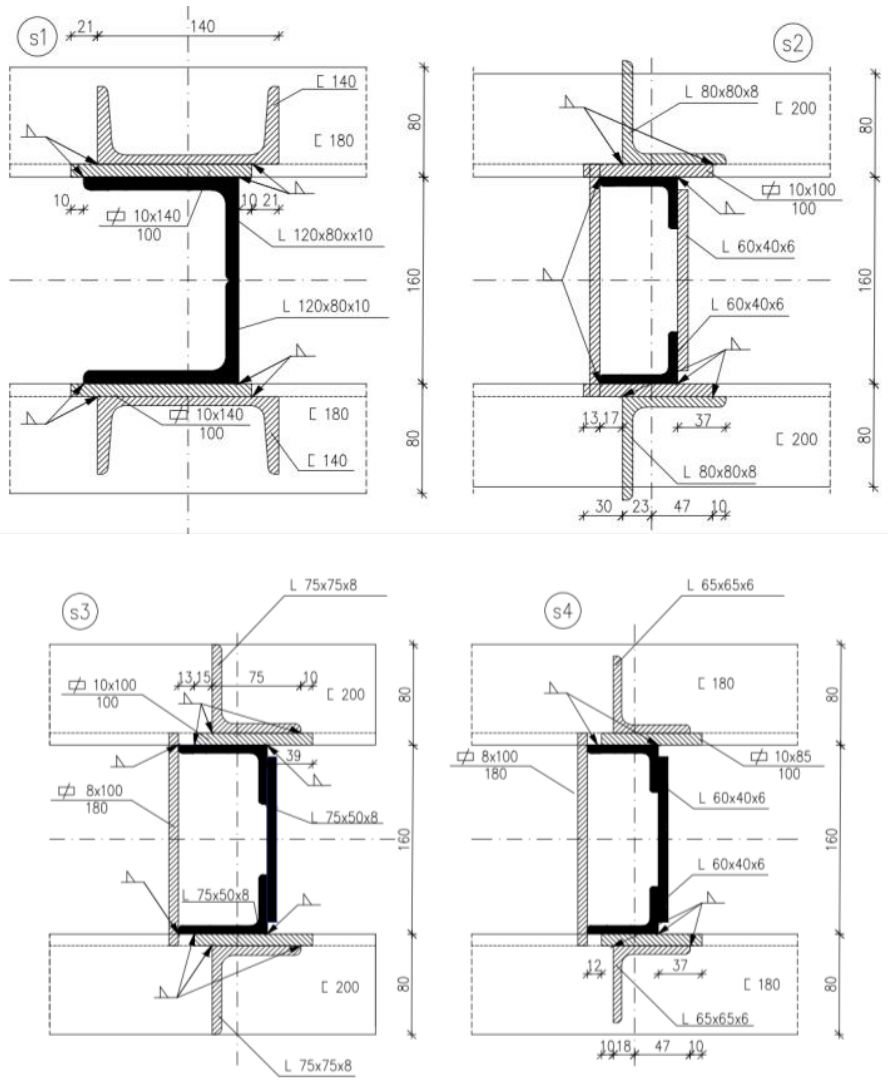

Fig. 6. Strengthened cross sections.

The static strength calculation for the strengthened structure were performed using EN 1993 1-1:2005, as described in the subchapter above. The results were summarized in tables 4 and 5 below.

Table 3. Capacity utilization ratio for truss members after strengthening, $y-y$

\begin{tabular}{|c|c|c|c|}
\hline Bar & Cross-section & \multicolumn{2}{|c|}{ PN-EN 1993-1-1 } \\
\hline & & water and steam & water \\
\hline 17 & $2 \mathrm{~L} 60 \times 40 \times 6+2 \mathrm{~L} 80 \times 80 \times 8$ & 0.30 & 0.55 \\
\hline 18 & $2 \mathrm{~L} 75 \times 50 \times 8+2 \mathrm{~L} 80 \times 40 \times 6$ & 0.63 & 0.90 \\
\hline 19 & $2 \mathrm{~L} 60 \times 40 \times 6+2 \mathrm{~L} 65 \times 65 \times 6$ & 0.37 & 0.68 \\
\hline 21 & $2 \mathrm{~L} 120 \times 80 \times 10+2 \mathrm{C} 140$ & 0.60 & 0.85 \\
\hline 22 & $2 \mathrm{~L} 120 \times 80 \times 10+2 \mathrm{C} 140$ & 0.76 & 1.00 \\
\hline
\end{tabular}

Table 4. Capacity utilization ratio for truss members after strengthening, $\mathrm{z}-\mathrm{z}$

\begin{tabular}{|c|c|c|c|}
\hline Bar & Cross-section & \multicolumn{2}{|c|}{ PN-EN 1993-1-1 } \\
\hline & & water and steam & water \\
\hline 17 & $2 \mathrm{~L} 60 \times 40 \times 6+2 \mathrm{~L} 80 \times 80 \times 8$ & 0.13 & 0.24 \\
\hline 18 & $2 \mathrm{~L} 75 \times 50 \times 8+2 \mathrm{~L} 80 \times 40 \times 6$ & 0.21 & 0.31 \\
\hline 19 & $2 \mathrm{~L} 60 \times 40 \times 6+2 \mathrm{~L} 65 \times 65 \times 6$ & 0.13 & 0.24 \\
\hline 21 & 2L120x80x10+2C140 & 0.44 & 0.63 \\
\hline 22 & $2 \mathrm{~L} 120 \times 80 \times 10+2 \mathrm{C} 140$ & 0.54 & 0.79 \\
\hline
\end{tabular}




\section{Summary and conclusions}

The subject of this paper was the deteriorated structure of a heat pipeline overpass. It was assessed in terms of safety and subjected to rehabilitation. The structure was found to be deformed due to loading of additional pipelines without adequate strengthening. Load bearing capacity of the structure was decreased also due advanced corrosion. The assessment of the structure was a complex problem due to lack of the documentation and incompatibility of the design codes, which were changing during the years of exploitation. Originally the overpass was designed according to the design code PN-62/B-03200 from the 1960's using the permissible stress method. The control calculation confirmed, it was designed properly. Currently, the modernized structure should fulfill requirements of Eurocodes. The performed analysis showed that some of the truss members exceeded ultimate limit states. The variety of possible solutions for strengthening were limited by the requirement to perform rehabilitation without even partial limitation in service. To strengthen the existing structures, angle and $\mathrm{C}$-shape profiles were welded to the existing structure. The provided solutions for one part of the structure were presented in detail.

\section{References}

1. A. Biegus A, Problemy oceny nośności modernizowanych konstrukcji stalowych, Inżynieria i Budownictwo, 2, pp. 76-80 (2018)

2. P. Kawecki P., W. Kawecki, J. Łaguna, Ocena stanu istniejącego konstrukcji stalowej estakady rurociągów przemysłowych, Inżynieria i Budownictwo, 5, pp. 236-239 (2019)

3. J. Ziółko, W. Włodarczyk, Z. Mendera, S. Włodarczyk, Stalowe konstrukcje specjalne, Arkady, Warsaw (1995)

4. M. Lutomirska, T. Lutomirski, Assessment of the technical condition of a deteriorated heat pipeline overpass before repair, XXVIII R-P-S Seminar, 661, Žilina, Slovakia (2019)

5. K. Pietrzak, W. Włodarczyk, O remontach i wzmacnianiu konstrukcji niektórych estakad pod rurociągi, Inżynieria i Budownictwo , 4, pp. 176-179 (2017)

6. PN-B-03200:1962. Konstrukcje stalowe. Obliczenia statyczne i projektowanie.

7. EN 1990:2002. Eurocode 0 - Basis of structural design.

8. EN 1991-1-1:2002. Eurocode 1: Actions on Structures. Part 1-1: General actions densities, self-weight, imposed loads for buildings.

9. EN 1993-1-1:2005. Eurocode 3: Design of steel structures. Part 1-1: General rules and rules for buildings.

10. C.Z.Chrysostomou, C. Nuti, G. Dieteren, New European Technical Rules for the Assesment and Retrofitting of Existing Structures, Publication Office of the European Union (2015)

11. A. Kozłowski, B. Stankiewicz, A. Wojnar, Obliczanie elementów zginanych i ściskanych wg PN-EN 1993-1-1, Inżynieria i Budownictwo, 9, pp. 477-484 (2008)

12. J. Gierczak, Przebudowy konstrukcji stalowych: część 4 - sprawdzenie stanów granicznych, część 5 - wzmacnianie konstrukcji, Builder (2016) 